\title{
Malang Mask Puppet in Era of Globalization: Social and Cultural Impact
}

\author{
Arining Wibowo \\ Department of Culture Studies, Faculty of Social and Communication, \\ Universitas Kebangsaan, Indonesia
}

Received: March 15, 2019. Revised: May 16, 2019. Accepted: June 19, 2019

\begin{abstract}
This article discusses socio and cultural impact as an effect of the commercialization of Malang mask puppet in the era of globalization. Padepokan Seni Asmoro Bangun located at Kedungmonggo Hamlet Malang Regency modifies the art of Malang mask puppet in order to turn the function of traditional art from ritual to the commodity. This research method is qualitative by using observation, interviews, and documentary studies for data collection. The result shows that modification creates three impacts, social and cultural impacts, also the occurrence of new senses in terms of Malang mask puppet includes creativity, prosperity, education, aesthetic, conservation, and identity sense.
\end{abstract}

Keywords: commercialization, socio, profane, cultural, impact, Malang mask puppet

How to Cite: Wibowo, A. (2019). Malang Mask Puppet in Era of Globalization: Social and Cultural Impact. Harmonia: Journal of Arts Research And Education, 19(1), 18-28.

\section{INTRODUCTION}

According to Suparlan as cited by Prasetyo (2017) cultural change is the turn of idea system of society which consists of rules, norms, values, and technology. The cultural change is the impact of modernism. The flow of modern life influences the surrounding society of Kedungmonggo Hamlet, Malang regency as well. The art of Malang mask puppet which was once precious and sacred art turns to be old fashioned and ignored local art. Malang mask puppet was once oral tradition and sacred art which was being considered as a tie between humans and god and humans and relatives and his/her surrounding society as well. As explained by Sibarani (2014, p. 54) that oral tradition encourages humans to socialize both with their family and social environment. Oral tradition was being considered as a communication medium. The impacts of oral tradition for society and their environment simply happens by watching, listening, and enjoying art performances.

Oral tradition alongside its content includes meaning, values, cultural norm, and local wisdom which is being stated by Sibarani (2014) is about "remembering the past, understanding the present, and preparing the future". Malang mask puppet as the oral tradition of Kedungmonggo Hamlet was functioned as a bonding of solidarity of its surrounding society. According to Kayam cited by Safarudin (2014, p. 169) that society will understand their values and behaviour pattern form tradi-

\footnotetext{
Corresponding author: Jl. Terusan Halimun No 37 Bandung, Indonesia

E-mail: arining73@gmail.com
} 
tional shows.

But, globalization and development bring society to the various side of reality such as comfort, pleasure, appearance, and freedom of desire. On the other side, Gildens (2001) predicts the existence of "huge threat in form of private meaning emptiness" as the impact of the lost of values and wisdom of the past (Ritzer \& Goodman, 2012, p. 610-611). Moreover, the development of modern art in the form of new amusement of television and the internet, which caught the attention of the young generation influences oral tradition, Malang mask puppet as well. Malang mask puppet once was forgotten. But then, nowadays Malang mask puppet tries to exist and survive in the era of globalization due to the effort of several art studios (padepokan) and artists.

Even though Malang mask puppet is being revitalized, according to Pratisto (2017) mask dance nowadays is being held in order to entertain audiences, whereas at the ancient ages it functioned as a sacred procession. The values of this oral tradition to worship god and ancestor fade away. Malang mask puppet has been out of its real context. Moreover, the aim of the Malang mask puppet performance as an entertainment medium is to make a profit. Malang mask puppet has become a commodity and traded product. The high frequency of tourism promotion of the government of Malang turns the art to the assets for the development of the regency. According to Brandt $T$ (1997) the centralized administration, better infrastructure, and better lifestyle are preferable in order to operate larger cities. Factors such as education, transportation, mass media, communication and other sectors as well are related to the change of socio-cultural aspects of society. As revealed by Pitana $(2015$, p. 115$)$ that tourism influences the socio-cultural life of society, but other factors take part in changing the condition of the socio-cultural as well. The change of Malang mask puppet brings several both positive and negative impacts include social, profane, and cultural impacts.
The art of Malang mask puppet includes dance and story performed by various masked figures. Based on Javanese ethnic society, this art is considered as an old traditional art due to the occurrence since the IX century (Timoer, 1980). In the show of Malang mask puppet, the dancers wear masks or kedok which cover their faces. Dancers play their characters by the guidance of the narrator (dalang). According to Kartodiharjo dance of Malang mask puppet formerly functioned as a religious ceremony for Hinduism at the era of Majapahit emperor and tradition such as animism, shamanism, and the worship of ancestors (Timoer, 1980, p. 11)

The tradition of masked dance functions as worshipping was being considered as a medium to free human from danger and get protection from their ancestor. The arrangement of this ceremony was being considered as the prevention of disaster and obstacles in man's life. The importance of masks and the role of the puppet was viewed as an absolute element of their life. At that time, Malang mask puppet grew and was considered as the appropriate art of the era. Malang mask puppet was admitted as a tradition to worship ancestors' spirits. But then according to Timoer (1980: 13) the realization of the ancestor's spirit changes. Alongside the revitalization, the simple shape of the mask turned to the smoothen and more beautiful shape. The function of mask changes as well, formerly as a medium of religious ceremony to the medium of art show (Timoer, 1980, p. 14).

The growth of moderate Islam and the development of modernism influence the changing function of Malang mask puppet. Padepokan Seni Asmoro Bangun, is located at Kedungmonggo Hamlet, Pakisaji, Malang regency, one of the art studios which still maintains Malang mask puppet. Malang mask puppet is succeeded to change its function from sacred to the profane art. Thus, Malang mask puppet regains its position in society and spreads its popularity. Growth and development of Malang mask puppet in Kedungmonggo 
Hamlet is started by Mbah Karimun and inherited by Kek Serun, a great-grandchild of Mbah Karimun. According to Hidayat (2008, p. 29), Kek Serun and another grandchild of Mbah Karimun participate to develop the art of Malang mask puppet at Kedungmonngo Hamlet. They gather and become dancers, players of gamelan, mask crafter. They have been faced with various and dynamic conditions, up and down for 25 years.

The rise of Malang mask puppet began in the middle of 1970 . Both old and young generations participated and held many shows in several big cities in Indonesia. In 1978, dancers of Kedungmonggo Hamlet held a performance in the presidential palace at the era of President Suharto. In 1980, Kedungmonggo Hamlet renovated Malang mask puppet. They renewed the quality of movement, performance, and products of Malang mask puppet. The result of this effort succeeded to brings Malang mask puppet to get a predicate as a local asset of Malang tributed by the Government of Malang. As admitted superior local asset, the government of Malang usually ask Kedungmonggo mask puppet to participate in several festival and cultural event in order to promote their local tourism (Hidayat, 2008, p. 42). Thus, because of the growth of Kedungmonggo mask puppet, the member changed its name to be Padepokan Asmoro Bangun. Asmoro Bangun is named after the main figure of Malang mask puppet, Panji Asmoro Bangun (Safarudin, 2003, p. 36). Now, Padepokan Asmoro Bangun is under the lead of Handoyo, as the heir of his pioneer.

In the performance of Malang mask puppet, there are several pieces of equipment needed to create a high quality of the art. Supporting equipment owned by Padepokan Seni Asmoro Bangun includes: Javanese Narrator called as dalang, puppet child, gamelan (Javanese music instruments), gamelan player, stage, and costume.

The meaning of Javanese narrator or dalang is a particular person who has a special talent in playing puppets. Dalang is the main artist in the mask puppet performance. Dalang functions as director, the writer, narrator, singer, music arranger, stage arranger, and dancer as well. As a narrator, dalang must have skills in controlling janturan (description about king or empire which is being narrated in form of poetry or specific monolog), cariyos or kan$d a$ (story), gunem or pocapan (the figures of dialog), suluk (Javanese poetry with special rhythm), dhodhogan (controller of musical composition of gamelan), and kepyekan or kepyakan (Supriayanto, 1997, p. 79). The main dalang of Padepokan Seni Asmoro Bangun is Kasnam who has been trusted as the best Javanese narrator of mask puppet because of his acknowledgment of pakem of Malang mask puppet. Dalang has an important role because the success of Malang mask puppet performance depends on him.

The puppet child is a team of actor who has good skill in mask dance. They have double roles because the costume arrangement of Malang mask puppet is possible to wear by double roles characters. The change of character needs only a change of mask (Supriyanto, 1997, p. 81-82). The number of puppet children depends on the story and the price of the show. The story of Walang Sumirang Walangwati, for example, has eight persons as puppet child.

Panjak or gamelan music player is a group of gamelan player accompanied by the choir in the show of Malang mask puppet. Panjak of Padepokan Seni Asmoro Bangun is group of local people of Kedungmonggo Hamlet who have known the art of Malang mask puppet.

Gamelan is the intruments of music. In the performance of Malang mask puppet usually includes laras slendro or laras pelog. While for East Javanese puppet, laras slendro is usually preferable. The series of gamelan are: bonang balok, bonang penerus, demung, saron, peking, gender balok, gender penerus, gambang, kendang, kethuk, kenong, kempul, and gong (Supriyanto, 1997, p. 88-89). Whereas, gamelan which is usually used at Padepokan Seni Asmoro Ban- 
gun is more simple includes kenong, ketuk, gong, bonang penerus, bonang babon, kendang, saron, peking, and demung. The arrangement of musical instruments and stage is aimed to make dalang easier to manage the flow of the show because dalang needs to unite panjak and dancers of Malang mask puppet.

The stage is a part of important equipment to support the success of show performance. In Malang mask puppet, the stage can be in the form of a permanent or temporary stage. The arrangement of the stage depends on the demand of audiences. The setting of the show influences type of stage, while the show holds in a building and appropriate place available to arrange gamelan, other properties, and decoration, the crew does not need to prepare a stage (Timoer, 1980, p. 73). Oppositely, if the show holds at the yard, the crew needs to prepare a temporary stage which is usuaaly called as terop. The model of the stage usually prepared for Malang mask puppet performance by Padepokan Asmoro Bangun is in form of pendapa.

Padepokan Seni Asmoro Bangun provides costumes for puppet children for the show of Malang mask puppet. Supriyanto $(1997$, p. 89) divides costume of Malang mask puppet into seven parts, include 1) head embellishment such as jamang, udeng, fabric to cover head, and wig 2) ear embellishment such as sumping, 3) masks as face embellishment 4) neck embellishment includes kace necklace and sampur, 5) hand embellishment includes klat bahu and dekes, 6) body embellishment such as kace, stagen, timang, keris ladrangan, and 7) foot embellishment, pants, rapek, socks and gongseng. Mask functions as the main complement of Malang mask puppet. The shape and color of the mask show the characteristic of the figures.

\section{METHODS}

Qualitative method is used in this research. The study focuses on the worker, artist, and society of Kedungmonggo Hamlet in terms of their effort to modify
Malang mask puppet as an oral tradition to the art product which can be traded. In qualitative research, the approach of the researcher does not have refer to the dichotomy of true or false, but rather stressing on the approach of the researcher itself (Ida, 2016)

Techniques of data collection are including observation, interview, and documentary study. Observation is aimed to see and observe the changes of the growing social phenomena, thus the change of assessments needed, for the observer to observes certain moments, then separates necessary data (Margono, 2007, p. 159).

According to Kurnia (2007), information taken from observation includes the doer, location, activity, object, action, incident, and time. The use of the observation technique is aimed to displays the realistic description of the work and event, to answers questions, helps human behaviour, and evaluates and measures certain aspects and gives feedback to the measurement. The use of observation is conducted by directly observe the activity and process in the field especially at the time of Malang mask puppet performance show. Observation is conducted also at the time when there is no performance show to obtain the situation and information in terms of the skill of the Malang mask puppet doer.

The interview is conducted by the researcher in the next step. The aim of the interview according to Nazir (1988) is a process of getting information in research by giving a question and asking answer face to face among the interviewer and informant. Interviewers as a technique of data collection use tools named as an interview guide. The interview is conducted by communicating with the data source. Communication is conducted by question-answer orally whether direct or not (I. Djumhur \& Surya, 1985). While according to Walgito (1987) interview is one of the methods to collect data both from child and adult by holding direct relation to the informant. Sukardi (1983) stated that the interview is a tool to get data or facts or information from students orally. The interview is 
conducted to get the data needed (Winkel, 1995).

Researcher conducts interview to the several respondents, they are Handoyo (owner, manager, doer, and crafter of Malang mask puppet at Padepokan Seni Asmoro Bangun), Tombro (doer and dancer of Malang mask puppet), Sunari (doer and art observer of Malang mask puppet), and Balok (art observer and researcher of Malang mask puppet).

The documentary study is the technique of data collection that is conducted by the researcher to get data based on the historical dan developmental process of Malang mask puppet. Definition of the document according to Gottschalk (1986, p. 38) is the authentication process based on written, oral, description and archeology. According to Bungin (2007) documentary study is one of the methods conducted in the qualitative approach to tract historical data. The documentary study helps the researcher to decide the level of credibility of the researcher based on the existed documents. The documentary study is conducted by the researcher by finding and seeing directly to the show of Malang mask puppet and the production of the skilled art of Malang mask puppet. The documentary study is also conducted to find the change and shape of Malang mask puppet at Padepokan Seni Asmoro Bangun and at several places such as Inggil restaurant where the display of various faces of Malang mask puppet can be found. The documentary study is conducted to find several references in the form of books and information related to the Malang mask puppet in Malang public library, bookstore, and internet.

\section{RESULT AND DISCUSSION}

The result and finding of this research is divided into three clusters, first explains the social impact of the modification of Malang mask puppet, second is the cultural impact, and third explains the senses of Malang mask puppet.

Social Impact of The Modification of
Malang Mask Puppet

The positive impact which can be considered as the social aspect of the modification process of Malang Mask Puppet is the increase of income and living standard. The surrounding society of Kedungmonggo Hamlet uses Malang Mask Puppet as their choice of daily occupation. Society including children, teenagers, and the elderly learn to dance dan carve the mask. These people live near to the Kedungmonggo Hamlet compete with each other to sell their product. As a show which is being performed once a month usually in Monday-Legi (based on Javanese calendar) and called as gebyak senin legian, Malang mask puppet attracts the society to participate. Tombro, one of the data resources said:

After Handoyo handles Seni Asmoro Bangun (name of one of traditional dance art studios in Malang), the mask becomes not only art but also a resource of a job. The job of product masks is now considered as a job, no longer becomes only part-time job [Tombro, 35].

Moreover, the decrease in unemployment is another positive impact. The bonding of togetherness and awareness to help each other event and performance of Malang Mask Puppet can be considered also as another social impact of the modification. After Handoyo succeeds in bringing Malang mask puppet to perform internationally, the people of Kedungmonggo including the elderly, children, and teenagers compete to participate. They assume that they can be productive by selling the assets through creation of traditional art. After Kedungmoggo Hamlet is signed as Kampoeng Topeng by JTv, many visitors come to enjoy the show performance, to study and research. This means that the modification process of Malang Mask Puppet gives a positive impact whether in the economic, education, and mass media sector of Malang.

The development and the improvement of Malang Mask Puppet which gives good and positive impact certainly are being followed by a negative and decreasing aspect. The modification process 
of Mask Puppet creates two management systems, the organization, and juragan (master) system. The organization system assumes to have members but the juragan system assumes to have workers. This system of management indicates the social and economical gap among the members of Padepokan Seni Asmoro Bangun. The gap includes a position in an organization setting, income, and job vacancy. According to Piliang (2011, p. 429) the segmentation based on their taste, so it creates the social contrasts. The contrast and segmentation system is really complicated and different from a person to another. It also has another difference level: the different levels of person, class, society, nation, and race. The gap among the members of the organization decreases solidarity and affects the development of Malang Mask Puppet. As stated by Suroso:

If Padepokan Seni Asmoro Bangun applicants these two systems of management (organization and juragan system), the gap among members is hard to be avoided [Suroso, 50].

The art of Malang mask puppet which is rooted in the oral tradition has deep aesthetic and sacred values. Malang mask puppet is being considered as the medium to worship and respect the ancestor's spirit. People held this ritual continuously and concerned about faith values. But, the art of Malang mask puppet faces the change of culture from time to time. Before becoming the art of castle which was performed by and for the noblemen, mask puppet was formly performed by and for civil society. The creature was even made from stone at that time. The sacred values of the Malang mask puppet as a custom ceremony created many calculations. The calculation includes the electing day of the ceremonial show or called naga dina, fasting three days continuously before the show, and choosing lakon, which is important to appropriate the representation of the hopes and goals of the ceremony. According to Kusmayati cited by Safarudin (2014), the ceremony is aimed to worships the ancestors, express gratitudes, ties to the life cycle, and relates to the appeal. But then, Malang mask puppet changes the role of the art from the medium of ceremony and ritual to the enjoyable performance.

Turning to the entertainment aspect, wayang mask Malang is being marked by omitting some sacred values Sunari, one of the data resources stated in the interview in July 2016:

The disappearance of the sacred values of the Malang mask puppet is being influenced by the inability of the old generation to transform and the young generation to absorb the religious context as well. As the medium of praying, the performance of Malang mask puppet contains the worship symbol of God as its basic philosophy. But, nowadays show, the focus turns to the visualization aspect. Religion values no longer become the main purpose of the ceremony [Sunari, 34].

The modification process of Malang mask puppet brings profane impacts. The increase of the market demand to turn Malang mask puppet to be commodity indicates the goal of profit. Padepokan Asmoro Bangun commercializes and gets the profit as the impact of the modification of Malang mask puppet performance. Tombro, is interviewed in December 2016 revealed:

The show of Malang mask puppet nowadays is different. The show follows the market taste. The limitation of duration and dancer compress the performance.

Tombro mentions the compression of Malang mask puppet as pethilan. Pethilan is the impact of modification that signs the profanation process of Malang mask puppet. According to Salim cited by Balok (2014, p. 172), the turn of cultural things to the commodity creates a larger production process, imitation, and reduces the quality. In the performance of art, the show is being packaged and modified in its several aspects which causes the loss of important philosophical values.

\section{The Cultural Impact of Modification of Malang Mask Puppet}

As an oral tradition, Malang mask puppet is being considered as one of the 
cultural assets and heritage of Malang. Thus, the original values of Malang mask puppet must be conserved and maintained. Even though this traditional art faces the transferring and inheritance process, the artist of Malang mask puppet must be able to create the strategy of inheritance to keep the existence of this art. In the globalization era, the modification process of Malang mask puppet at Padepokan Seni Asmoro Bangun indicates the desire and market taste to turn the art to the commodity. According to Piliang (2004, p. 197), the openness to the other culture, interaction, and exchange process which is possible must be completed with critical thinking. There must be a mechanism of cultural filter which possibly minimalizes the culture to the other.

The packaging show of traditional art is considered as needed to appropriate customer demand. This modification process is the big factor in the loss of the original values and meaning of Malang mask puppet. First, the influence of the modification process impacts the limited duration of the show. Malang masks puppet performance which has to be held during all night changes to only two hours. The philosophical values change the economical values as well. Moreover, the development of technology put the art of Malang mask puppet easier to enjoy. People do not need to attend directly to the show performance and possibly to re-watch repeatedly via television, radio, internet, and other digital media. Malang mask puppet which has been medium of praying and worship to the ancestors changes its function as the commodity to fulfill the need of artists and workers. Malang mask puppet support the surrounding society as well.

Based on history, the rising of Malang mask puppet at Kedungmoggo Hamlet is in the era of preaching of Hindu. Eventhough many hindu temples can be found as the proof of the preaching, these historical sites change to be an organization nowadays. The preservation of traditional art such as dance, karawitan, and skill art occurs.

\section{The Senses of Malang Mask Puppet The creativity sense}

The turn of the function of Malang mask puppet from the medium of ritual to the public theather creates a new important role for the surrounding society of Kedungmonggo Hamlet. Malang mask puppet solves problems which are happened in this region over the years. According to Kasim cited by Iswantara (2000) that since the ancients ages, the public theater is functioned as the facilities to ask society participation directly. As a public theater, Malang mask puppet performance gives simple and easy-accepted communication. Thus, Malang mask puppet becomes the medium to solve the developmental problems of the surrounding society. This oral tradition nowadays creates welfare and prosperity for people of Kedungmonggo Hamlet. According to Wardana (1984, p. 40), the function of oral tradition can be slaved on social importance and being part of the social life from time to time. According to Piliang $(2003,249)$, the change of meaning is caused by the process of encoding which reproduces meaning by the standard of other text as its reference. The rules such as "similitude" and "resemblance" are applicated without considering deeper semiotical dimensions such as concept, content, idea, meaning, myth, or ideology.

Moreover, during a long period of time, Malang mask puppet faces various kinds of changes whether in terms of its form and function. The changes of Malang mask puppet affect its represented meaning. According to Piliang (2003, p. 249), the changes of meaning occur because of the encoding process. Beskalan Putri dance is one part of Malang mask puppet whose meaning changed. The prior function of this dance is to represent the fertility ceremony and welcome the ancestor's spirit. This dance is originally held at the ceremony such as opening a new area or building a house.

However, because of the pattern of inheritance, this dance was modified as a welcoming dance performance. Its function is entertainment. Princess Beskalan 
dance became a tourist attraction.

Considering the iconic character of Beskalan Putri dance, the modification shows the loss of ideological values and the rise of the beautification of art. In the name of creativity, Padepokan Asmoro Bangun creates a new pattern and renovates this dance. The number of dancers, limitation of duration, choreography arrangement, briefing story plot, janturan, kandha, antawacana, and sulukan/lagon and stage adaptation become the focus to modify. Malang masks puppet function changes to commercialize and creates jobs for the people of Kedungmonggo Hamlet. Various kind of creativity occurs and creates new art of Malang mask puppet show, its dances, and handicrafts.

\section{The prosperity sense}

In terms of the modification process of Malang mask puppet, Padepokan Asmoro Bangun has a specific strategy and plan to support the surrounding society. One significant purpose of this art modification is to increase the prosperity of the local people of Kedungmonggo Hamlet. The increase of income which possibly helps surrounding society to fulfill their daily needed becomes the concern of modification. The development of tourism in Malang influences the growth of Malang mask puppet. Padepokan Asmoro Bangun formulates three basic patterns to support the development of tourism in Malang. First, the place as destination tourism has to be beautiful and unique. Second, people who live around tourism site characterize as kindly residence, friendly, give secure, comfort and prime services to the visitors. Third, parcel as products that represent the culture and uniqueness of the place. The parcel which functions as the handicraft is portable and represents memories. Thus, parcel gives the visitors the vibe to remember or desire to come back to this tourism site.

Revitalization of Malang mask puppet as the local culture of Malang extends profit for its society. An increasing number of visitors and tourist whether from another region of Indonesia or even another country establish productivity related to the Malang mask puppet. This art is being commercialized in order to open new job vacancies and creates a prosperous society. As stated by Sutarto (2004, p. 58 ) that the function of local and cultural products which is still in the process could support the growth of the tourism industry and produce many devices.

But this shows that the changing meaning of Malang mask puppet turns from sacred to profane. Due to the perspective of Padepokan Asmoro Bangun which considers Malang mask puppet as the medium to support its surrounding society to fulfill their daily needed. Malang mask puppet then becomes the playground to get jobs and occupations. This condition is unavoidable due to the change of sociocultural background as well. Globalization flow brings influences to the Padepokan Asmoro Bangun to change the function of Malang mask puppet.

\section{Education sense}

Malang mask puppet takes an important role to build and teach manners toward children. Fun learning media such as Malang mask puppet contributes to the education aspect through the story. The story contains moral messages to guide children to choose a better way of life. As revealed by Sutarto (2004, p. 35), the Malang mask puppet as the cultural identity has the potency to be developed, whether in terms of aesthetic of art or educational sense. Panji, as the main figure of Malang mask puppet, is the one significant example of a hero who could possibly becomes role model.

Besides moral messages, education for children is being applied through dance training and practice. Pendapa (studio) of Padepokan Asmoro Bangun becomes the place for children to learn and dance. The learning process creates togetherness and respect without considering one's social degree. Children are being taught about solidarity, helping each other, and peace. 


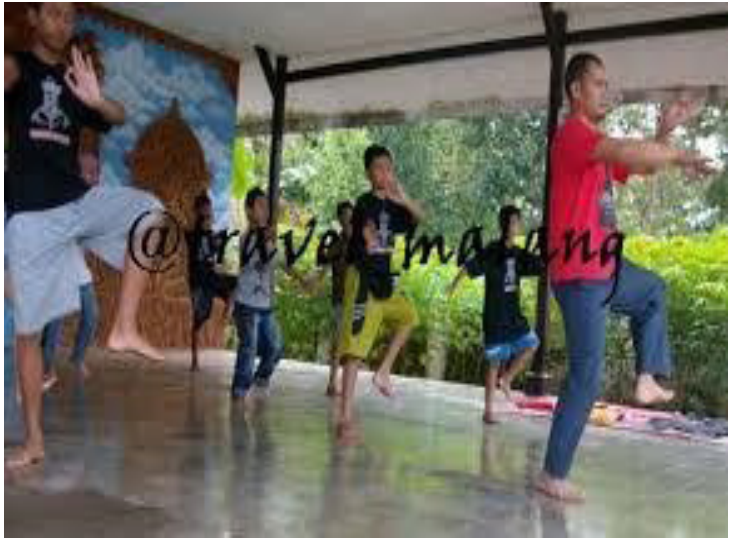

Figure 1. Children learn to dance at Pendapa

\section{The aesthetic sense}

The aesthetic sense of Malang mask puppet is being represented through artist, dancer, and audience. These stakeholders have role to express values of Malang mask puppet itself. That's why the change of generation influences the aesthetic sense of Malang mask puppet. At Kedungmonggo Hamlet, the change of the meaning of mask puppet itself begins from the change of pakem especially in terms of dance choreography. The old generation considers Malang mask puppet as a guidance due to the representation of philosophy of life. Malang mask puppet contains the balance of nature and human alongside with their religious aspect. Oppositely for nowadays society, Malang mask puppet is being considered as an entertaining dance which attracts people. Malang mask puppet becomes a product whose dance movement and custom are modified. Bapang dance for example originally portrays a figure with the firm character who is marked by wide hand movement, moves left to the right, wide eyes, long nose, and red coloured mask. Bapang dance portrays the bad character as the enemy of Panji. Whereas at this time, Bapang dance is simply being understood as the icon of Malang.

The understanding of the audience toward the aesthetic values of Malang mask puppet is limited only from two hours show performance include dance and story. While dancing and story have been packaged to match the demand for a more enjoyable performance. As stated by
Rusyana (1999, p. 2) that tradition could be a part of a culture that is being a common reflection of the whole culture, then it has a certain meaning for the supporting society. Malang mask puppet as an oral tradition has a dynamic characteristic to change its structure and function. The existence of Malang mask puppet in the era globalization follows its social context.

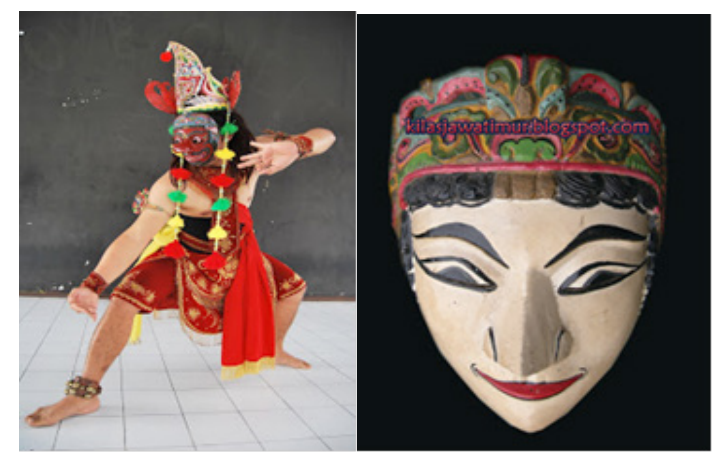

Figure 2. The Aestethic of Malang Mask

\section{The conservation sense}

Even though Malang mask puppet has existed in various places of Malang, Padepokan Asmoro Bangun strongly conserves and maintains traditional art. Located at Kedungmoggo Hamlet, Pakisaji as one subdistrict of Malang, this art studio has been tried several efforts to maintain Malang mask puppet from extinction. The renewal of the inheritance system is significantly being chosen. The inheritance system of Malang mask puppet is called ngabdi for the very first time. Ngabdi which means one has to be student who follows particular ritual to be accepted and had chance to learn the art of Malang mask puppet. While nowadays, Padepokan Asmoro Bangun changes its system and allows every person to learn and practice dance on Sunday. The schedule is even possibly being appropriated to the demand of participants. Moreover, the permission of girl participation adds the number of students.

The conservation effort of Malang mask puppet succeeds to add a number of participants in dance training because it attracts not only adults but also teenagers and children. The result of this training brings children to show their talent at the 
event of Gebyak Topeng Senin Legian. This proves the effort of Padepokan Asmoro Bangun to develop the next generation in order to maintain the art of Malang mask puppet.

\section{The identity sense}

As an oral tradition that has developed at Malang, the art of Malang mask puppet becomes a reflection of the cultural identity of this regency. Thus, Malang mask puppet attracts the heirs, artist, and its supporting society because of its important role to build up the identity of Malang. The function of Malang mask puppet is important for the life of its surrounding society, as revealed by Koendjaraningrat (1984, p. 286) due to the ability of Malang mask puppet to spread and functioned as a social medium. As traditional shows which turn to be public (popular) art, Malang mask puppet reaches each layer of the society of Malang. Moreover, it becomes the identity of a certain group of people. Including students, such as a student of State University of Malang (UM), Kanjuruhan University of Malang, or Santo Yosep Senior High School who come to Padepokan Asmoro Bangun for studying and researching about Malang mask puppet. Even the researcher comes both from another local region of Indonesia and another country such as Japan. The existence and meaning of Malang mask puppet attract a particular group of people to own information and collect data about it. According to Piliang (2011), cultural identity is the process of becoming. It does not mean only an existence which has passed the time, place, history, or culture, but also the presence of learning and association process of it.

\section{CONCLUSION}

The turn of Malang mask puppet form the sacred and traditional art to the profane and popular show at Kedungmonggo Hamlet indicates the influence of globalization flow. Once an art enters the globalization flow, it must follow the rule of global. As a local asset of Malang, Ma- lang puppet mask is considered to have a role in supporting the development of Malang City, both in terms of economic and cultural assets. Some art studios (padepokan) include Asmoro Bangun, then modify Malang mask puppet and turn its functions as commodities and products. The modification process on the other side is indeed the effort of Padepokan Seni Asmoro Bangun to maintain dan conserve Malang mask puppet. The modification process of Malang mask puppet creates not only job vacancies, but also awareness of the heirs and surrounding society to work harder to revitalize and develop their traditional art. Whereas, while an artist is being modified, several loss follows. Sacred and philosophical art is turned to be an entertaining show. The sacred and philosophical side of Malang mask puppet contains local wisdom and continual guidance of life. Meanwhile, the fun show creates the occurrence of several aspects, such as prosperity, identity, creativity, education, etc. This signs ambivalence of the modification process, because positive and negative impact equally occurs.

\section{ACKNOWLEDMENT}

This research was supported or partially supported by Lembaga Pengelola Dana Pendidikan (LPDP) RI as one of the funding agencies and credible scholarship in Indonesia. I am also grateful, thanks to Aquarini Priyatna for her assistance with brilliant guidance, Cece Sobarna and Sutiyono Mahdi who moderated this paper and in that line improved the manuscript significantly.

\section{REFERENCES}

Andalas, E. (2016). Sastra Lisan Lakon Lahire Paji Pada Pertunjukan Wayang Topeng Malang (Kajian Sastra Lisan Ruth $\mathrm{H}$. Retrieved from http://repository. unair.ac.id/60715/

Balok, S. d. (2014). Dampak Komoditas in Seni Budaya. Surakarta: ISI Press.

Brandt, T. (1997). "Kunci Budaya" Business 
in Indonesia The cultural keys to success. Jakarta: PT Intermasa, Jakarta.

Bungin, M. B. (2008). Penelitian Kualitatif; Komunikasi, Ekonomi, Kebijakan Publik dan Ilmu Sosial Lainnya. Jakarta: Kencana.

Giddens, A. R. (2001). Bagaimana Globalisasi Merombak Kehidupan Kita. Jakarta: Gramedia.

Gottschalk, L. (1986). Understanding History; A Primer of Histirical Method. Jakarta: UI Press.

Hidayat, R. (1999). Makna Simbolis Empat Tokoh Sentral Pada Wayang Topeng Malang. Reasearch Report. Malang: Universitas Negeri malang

Ida, R. (2016). Metode Penelitian Studi Media dan Kajian Budaya. Jakarta: Prenada Media Group.

Koentjaraningrat. (1984). Pengantar Ilmu Antropologi. Jakarta: Aksara Baru.

Kurnia, A. (2014). Penelitian Kualitatif. Dunia Penelitian .

Margono, S. D. (2007). Metodologi Penelitian Pendidikan Komponen MKDK. Jakarta: PT. Rineka Cipta.

Soehardi, . (2012). Nilai-Nilai Tradisi Lisan Dalam Budaya Jawa. Jurnal Humaniora, 14(3), 1-13. https://doi. org $/ 10.22146 /$ jh.763

Piliang. (2003). Hipersemiotika (Tafsir Cultural Studies atas Matinya Makna). Yogyakarta: Jalasutra.

Piliang. (2007). Proses dan Interaksi Budaya. Jakarta: Estetika.

Pratisto, C. (2017). Padepokan Seni asmoro Bangun. Bukti Hidupnya Malang mask puppet. Jurnal Resital .

Prawitasari, F. (2017). Padepokan Asmoro
Bangun. Bukti Hidupnya Malang mask puppet. Jurnal Resital dan Kompas.com .

Ritzer, G. d. (2012). Teori Sosiologi Modern. Jakarta: Kencana.

Rusyana. (199). Penggalian dan Penggarapan Karya Sastra. repository.upi.edu .

Safarudin, K. d. (2014). Komodifikasi Pertunjukan Malang mask puppet in Era Globalisasi. Harmonia .

Safarudin, K. d. (2014). Nilai-nilai Sakral in Pertunjukan. Jurnal Humaniora, 169.

Sibarani, R. (2014). Kearifan Lokal (Hakikat, Peran dan Metode Tradisi Lisan). Jakarta: Asosiasi Tradisi Lisan.

Suanda, E. (2005). Topeng. Jakarta: Pendidikan Seni Nusantara.

Soehardi, . (2012). Nilai-Nilai Tradisi Lisan Dalam Budaya Jawa. Jurnal Humaniora, 14(3), 1-13. https://doi. org/10.22146/jh.763

Supriyanto. (1997). Struktur, Simbol dan Makna Malang mask puppet. academia.edu .

Timoer. (1980). Mask puppet Malang: Lakon Lahire Panji. jurnal-online.um.ac. id.

Walgito, B. (1987). Pengertian Teknik Wawancara. Dunia Penelitian blokspot.com.

Wardhana. (1984). Pelatihan dan Penelitian Tradisi Lisan. repository@UPI. Bandung.

Yanuartuti, S. (2016). Building Creative Art Product in Jombang Regency by Conserving Mask Puppet. Harmonia: Journal of Arts Research and Education, 16(1). https://doi.org/10.15294/ harmonia.v16i1.6148 